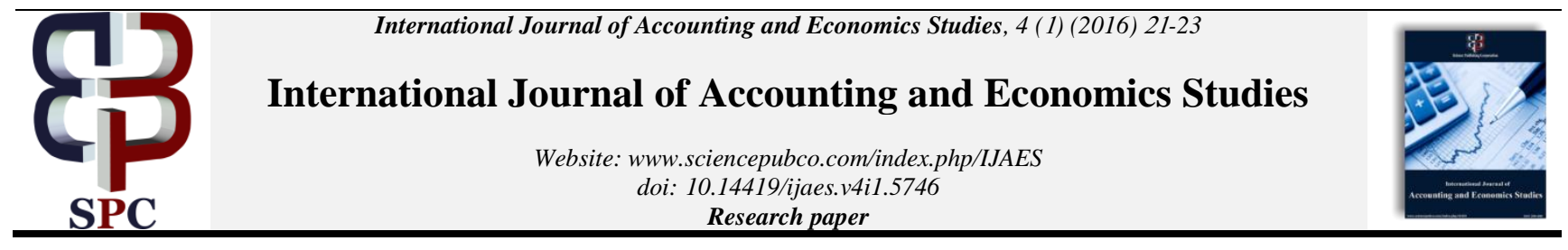

\title{
The effect of managerial overconfidence on investment
}

\author{
Mahmoud Lari Dashtbayaz ${ }^{1 *}$, Shaban Mohammadi ${ }^{2}$ \\ ${ }^{I}$ Assistant Professor in Accounting, Qaenat Branch, Islamic Azad University, Qaen, Iran \\ ${ }^{2}$ Master Student in Accounting, Hakim Nezami University, Quchan, Iran \\ *Corresponding author E-mail: shaban1362@gmail.com
}

\begin{abstract}
Overconfidence or experience-based learning theory in behavioral finance is a subsidiary of confidence. One of the most detrimental behavioral biases in the field of behavioral finance is that investors will manifest as a lack of understanding of the risk of capital loss, the transaction or the transaction repeatedly to find a hot stock and widely traded futures and having a non-diversified portfolio, all serious risks for the enterprise you are looking for. One of the implications of each common biases of overconfidence, lack of foresight is real. Therefore, it is necessary to protect investors against overconfidence and financial advisors to help them in this regard. Overconfidence leads investors to predict their skills over estimate and find the belief that they cannot market timing. Detection and mitigation of confidence too, is a fundamental step in designing the foundations of a good financial plan. Too much trust in their own people, the strongest findings in the psychology of judgment. In this paper, the risks of overconfidence management and examine its impact on investor portfolios.
\end{abstract}

Keywords: Managerial Overconfidence; Investment; Portfolio Investment; Potential Investors.

\section{Introduction}

Overconfidence is one of the managers' personality traits that influence risk (Duellman et al., 2015). Overconfidence managers may affect the auditor's risk assessment of financial reporting, as more reliability, probability and impact of favorable developments on the company's cash flow estimate more than the reality and possibility and effects of negative events than the fact evaluate (Heaton, 2002) and (Malmendier \& Tate, 2005). On the other hand a direct relationship between increased risk of distorting financial statements and the directors have confirmed overconfidence and on the other hand, they have no evidence to show that the characteristics of the audited accounts for overconfidence managers linked with increased risk. If auditors become aware of managers' personality characteristics, can be expected to know the risk factors and focus on audit planning and for greater efforts to reduce detection risk, they demand higher wages. Therefore, the outcome can be considered as the effect and consequence of the financial reporting risk. The theoretical point of view, the higher level hypothesis (Hambrick, \& Mason, 1984) states that the properties of the senior managers, decision making that affects them. One of the interesting features of management is overconfidence. Psychologists have concluded that people with high confidence, your chances of succeeding are overestimated, owes his success to his ability to understand and mainstream the role of chance and external factors in this less-than-evaluate (Van et al., 2007). Overconfidence bias and behavioral characteristics of a person who can be a false beliefs (positive) in relation to any aspect of the event in a state of uncertainty defined, then the mean estimate will be overstated (Skala, 2008 ). (Chayz et al., 2014) as overconfidence in research management and tax avoidance effect of managerial overconfidence on their tax avoidance. The results of this study showed that overconfidence management puts significant positive effect on tax avoidance. Overconfidence management, cash effective tax rate increases 1.5 percent. (Chen et al., 2010) level of family and non-family corporate tax avoidance compared with each other, and came to the conclusion that family firms than domestic competitors, the less avoid paying taxes. The companies represent a unique conflict between major shareholders and wisdom is formed. Good name and reputation of the state audit and lower incentives for tax avoidance. (Schrand, \& Zechman, 2011) argue, not only because of the high esteem in some situations lead to poor decision making, it will evaluate managers is a negative factor. Sometimes bad decisions or bad leaders may be optimistic, but in general, every company needs for success to the presence of people like them. (Ahmad and Duellman, 2013) showed that overconfidence of conditional conservatism decreased and be unconditional and strong external oversight, the relationship between these two variables is not affected. (Schrand, \& Zechman, 2011) stated that managers are more likely to report more reliable provider wrong due to insufficient surveillance on them. When people say 90 percent certain events will occur or statement is true, perhaps only 70 percent of the time they are right. Learn uncertainty makes investors have over-estimated their prediction skills and believe that they can time (changes) to determine their market. Studies have shown that one of the side effects of investor overconfidence, excessive increase in transactions. There is evidence that financial analyst to slow its previous assessment of the company's future performance modification, even when the evidence is strong that the current assessment is wrong. People often rely too much on their abilities and knowledge and information analysts and investors in areas that are relative, more than expected to have confidence when estimating the value of a share, for example, investors too confident, very low deviation to consider the whole expected returns, for example, about 10 percent of the profit or loss, as the experience shows greater standard deviation. The implication of such behavior is that investors risk losing their original capital 
underestimated. (Naturally, the higher the risk on the other side, there is a concern). In general, most primitive form, unnecessary and unjustified overconfidence of faith to the intuitive reasoning, or judgment of a person's cognitive abilities can be overconfidence groups to anticipate and to ensure shared overconfidence. Learn to anticipate a situation in which investors have confidence when estimating investment decisions, investment forecasts are very few do. One of the follies of this bias is evident that investors may thus building up unnecessary risks in their portfolios, downside risks less than the estimate. Overconfidence represents a condition to ensure that investors are too confident in their judgments. A common outcome is that the investors mind when identifying investment opportunities with the belief that this investment is not perfect, but the deal too low, leading to investors in search of the best opportunities for the next. So there is a good chance that investor's biases come under certain, limited portfolio investment transaction with the least diversity and abundance, hold. Also, many investors are so sure about their judgments, this type of cross-confidence "comes the confidence to make" arising. For example, the decision to invest in a particular company, often ignoring expected losses and later if the company is underperforming, they feel surprise or discontent. These people often do big deals and the portfolio are not diversified enough of that. The "overconfidence in confidence" and "trust the forecast calls" field can lead to wrong investment. Overconfidence leads to overestimating knowledge and skills and downplay the risks. It also leads to the feeling that you can control the issues and events, while in fact it is not. Overconfidence managers are more likely to overestimate future investment returns, hence more safety managers to overestimate the severity of future shocks positive cash flow of projects running led so would underestimate the negative shocks the future cash flow. Over the long-term safety managers continue their activities and to reduce the cost of investment is optimistic. So overconfidence lead managers are likely to underestimate the cost will be. This overconfidence in predicting costs and sales management will apply. In this case, the decision-making managers who lead by their actions and motives can affect the survival, success and failure in a word, performance and value of the company.

\section{The consequences of error of overconfi- dence in investment}

In discussing the investment, investors have too much confidence in their abilities. They narrow the possibilities to apply in the forecasts. The risk of loss of capital is underestimated. Also, most investors are so sure about their judgments. Basically, people tend to have high confidence in the accuracy of their judgments.

1) Negative information about their investment and their ability to consider not over-estimate their assessment.

2) They do frequent trading voluminous and that the average yield will be less than the average market return.

3) Non-diversified portfolios they choose. And risk losing their capital under evaluation.

\section{Behaviors caused by overconfidence bias behavior and its impact on an investor's portfolio}

1) Investors too sure of its ability to assess a company as an investment object, too estimate. As a result of negative information that normally is a warning sign that should not be taken buyouts or if the purchases made, to sell, to ignore.

2) Investors too sure of the result of the belief that they have specific information (not others) do big deals. Experience has shown that excessive trading, often leading to poor returns in the long run.

3) Investors over the historical performance of your investment or do not know or do not care, it may risk losing your prin- cipal underestimated; the result is generally poor performance and unexpected portfolios awaiting them.

4) Investors too safe, non-diversified portfolios they hold, so without a corresponding change in the risk-taking capacity, tolerate more risk. These investors are often not aware that they risk even more than they have the capacity for it, have undertaken.

\section{The risk of overconfidence managers}

1) Baseless belief with respect to its ability to identify stocks for potential investors: Too many investors make, claim that has above average talent, but there is little evidence to support this claim. The study showed that after deduction of transaction costs (before tax) average investor, approximately $2 \%$ per year, performance was weaker than the market average. Many investors too sure also believe that mutual funds are able to choose their future performance superior to others. However, many tend to be in and out of the fund, at the worst possible time deal because they pursue unrealistic expectations. The actual figures show that between Salhay1995-1984, a mutual fund's annual return averaged $12 / 3$ precent, while the average investor who has invested in a fund, the performance gain is equal to $6.3 \%$. Investment advisors when faced with customers who claim the ability to predict the next hot stock, you should ask them to review the historical performance last two years, if not always, but often, poor performance will be observed.

2) recurrent transactions (volume up): The average outstanding volume (turnover) per person per year in their portfolios was $80 \%$ (slightly less than $84 \%$ of the average turnover mutual fund is invested. 20 precent of investors in terms of portfolio turnover (an annual turnover of about one precent) annual return of 17.5 precent, compared with an efficiency of 16.9 precent have acquired the index S \& P500, show better performance during this period. In contrast, 20 precent of investors in terms of portfolio flow (Monthly circulation of about 9 precent or 108 precent annually), yields were $10 \%$. The researchers claim that the evidence confirmed evidence of this factor provides risk. Once an investor turnover shows a very high volume of transactions, the best advice is which dealings ask him to review the historical records and calculate your return. This shows the harmful effects of excessive trading. Since overconfidence is a cognitive bias, updated information, investors can often misunderstood the way help them.

3) Understand the risk of loss of capital: Investors too sure, especially those who are prone to overconfidence in predicting, tend to risk a decline in prices and a loss of original capital less than the estimate. They are very reliable over its forecast and the probability of losses in their portfolios is not considered enough. For advisors whose clients have this type of behaviour, offered a two-part recommendation. First, the investment characteristics to look for potential weak performance review of the evidence to show the dangers of over-reliance use.

Second, they refer to the studies in this field. It is often seen that investors at this point, calls to mind that Misspend unexpected swing reminds markets and a more cautious behaviour

4) The lack of diversification of portfolios: As a retired director who can take heart from their previous company's shares. Many investors are too confident, non-diversified their portfolios because they do not believe the securities that have been advocated in the past, has performed poorly, do not give up. In the case of companies for their outstanding performance the past, the bulk of the portfolio allocated, Consultant may hedge strategies such as providing sales and floating rate bonds recommend. 


\section{Conclusion}

The cash flow impact of the investment company, because it was cheaper than external financing, managers have more control over it. Thus, the final cash flow changes are possible to change the sensitivity of investment and financing cash flows result. In addition to the mainstream cash flow sensitivity of investment firms and market conditions, influenced by personal characteristics such as self-confident managers are also excessive. Managers have this feature, because of their excessive optimism to invest in projects that lack the cash flow needed to achieve the expected return on shareholders. The sensitivity of investment to cash flow in companies whose managers are confident too high. Between experience and risk appetite, overconfidence and herding behaviour of investment managers are highly significant relationship. Thus, the experience with risk-taking and overconfidence managers' inverse relationship between experience and herding behaviour there is a direct relationship. With increasing experience of managers, they are more in control of herding behaviour. Given the inverse relationship between risk-taking and herding behaviour can be said that one of the reasons less experienced administrators tend to earn higher returns on herding less, the degree of risk aversion is lower and more risk-taking. Because of the inverse relationship between experience and risk taking, as well as experience and confidence too, less experienced managers than more experienced managers with more confidence and more risks are too. Between experience and return on investment manager's inverse relationship exists and less experienced managers earn higher returns compared to more experienced managers.

\section{Acknowledgement}

I value the efforts of Mr. Ali Mohammadi in order to appreciate the support and cooperation.

\section{References}

[1] Ahmed, A.S. \& Duellman, S. (2013). Managerial overconfidence and accounting conservatism. Journal of Accounting Research, 51(1): 1- 30. http://dx.doi.org/10.1111/j.1475-679X.2012.00467.x.

[2] Chen, S., Chen, X., Cheng, Q. \& Shevlin, T. (2010). Are family firms more tax aggressive than non-family firms. Journal of Financial Economics, 91(1): 41-61. http://dx.doi.org/10.1016/j.jfineco.2009.02.003.

[3] Chyz, J., Gaertner, F., Kausar, A. \& Watson, L. (2014). Overconfidence and Aggressive Corporate Tax Policy. Available at SSRN: http://ssrn.com/ abstract=2408236.

[4] Duellman, S., Hurwitz, H. \& Sun, Y. (2015). Managerial Overconfidence and Audit Fees. Journal of Contemporary Accounting \& Economics, 11(2): 148-165. http://dx.doi.org/10.1016/j.jcae.2015.05.001.

[5] Hambrick, D. \& Mason, P. (1984). Upper echelons: the organization as a reflection of its top managers. Academy of Management Review, 9 (2): 193-206.

[6] Heaton, J. (2002). Managerial Optimism and Corporate Finance Financial $\quad$ Management, $31(2): \quad 33-$ http://dx.doi.org/10.2307/3666221.

[7] Malmendier U and Tate G. (2005). CEO Overconfidence and Corporate Investment. Journal of Finance 6 2661-2700. http://dx.doi.org/10.1111/j.1540-6261.2005.00813.x.

[8] Presley T and Abbott L. (2013). AIA submission: CEO overconfide dence and the incidence of financial restatement. Advances in accounting, Incorporating Advances in International Accounting 29, 74- 84. http://dx.doi.org/10.1016/j.adiac.2013.03.007.

[9] Schrand, C.M. \& Zechman, S.L.C. (2011). Executive overconfidence and the slippery slope to financial misreporting. Journal of Account ing and Economics, 53(1-2): 311-329. http://dx.doi.org/10.1016/i.jacceco.2011.09.001.

[10] Geigr Marshall A. \& Raghunandan, K. (2002) "Going- Concern Opin ions in the "NEW" Legal Environment" Accounting Hori zons .Vol. 16 NO. 16.

[11] Skala D. (2008). Overconfidence is Psychology and Finance-An Interdisciplinary Literature Review 143-33-50.
[12] Wan, F., Huang, D., Lan, Q. \&Yang, X. (2007). Numerical simulation for influence of overconfidence and regret aversion on return distribution. System engineering theory \& practice, 27(7): 10- 18.

[13] Myers J, Myers L,omer T. (2003) Exploring the term of the auditor - client relationship and the quality of earnings: a case for mandatory auditor rotation? The Accounting Review. 78: 779-99. http://dx.doi.org/10.2308/accr.2003.78.3.779.

[14] Meyer, J John T .Rigsby, Boone,J. (2007) “ The impact of auditorclient relationship on the revesal of first- time audit qualifications", Managerial Auditing Journal, Vol. 22 Iss: 1, pp. 53- 79.

[15] Tu, G. (2012) Controller changes and auditor changes China Journal of Accounting Research pp. 45-58.

[16] Walker, M. (2003). Principal/ agency theory when some agents are trustworthy, Accounting and Finance working paper, Manchester: Manchester Business School, Manchester University. 